\title{
MODEL DINAMIS INVESTASI DI INDONESIA PERIODE TAHUN 2004-2007
}

\author{
Oleh: \\ Andini Eka Sulistiowati \\ Staff PT. Bank Mega, Tbk Bali \\ E-mail/No. Hp: Ndien_embul@yahoo.com /085259535564
}

\begin{abstract}
This research aims to detect national income variable influence, credit rate of interest level and domestic investment previous period towards domestic investment with detects which variable that has influence dominantest towards domestic investment. Method which is used in this researcd is double linear regression PArtisl Adjustement Model used for perceiving short-range and long-range responsivenees from dependent variable to one changed unit of independent variable value. After conducted by t-test known that national income and previous period of the domestic investment individually having influence significantly to the level domestic investment. But credit rate of interest level individually not having influence significantly to the level domestic investment. The influence variable to the level of domestic investment is the level of previous period domestic investment model because analysis model that used is adjustment of partial model. Outside independent variable, in the reality variabel that influencing to the level of domestic investment is national income.
\end{abstract}

Keywords: domestic investment, dynamic model

\section{PENDAHULUAN}

Stok modal atau investasi merupakan salah satu faktor penting dalam menentukan tingkat pendapatan nasional. Kegiatan investasi memungkinkan suatu masyarakat terus menerus meningkatkan kegiatan ekonomi dan kesempatan kerja, meningkatkan pendapatan nasional dan taraf kemakmuran (Sukirno, 2000). Adanya investasi-investasi baru memungkinkan terciptanya barang modal baru sehingga akan menyerap faktor produksi baru yaitu menciptakan lapangan kerja baru atau kesempatan kerja yang akan menyerap tenaga yang pada gilirannya akan mengurangi pengangguran. Dengan demikian terjadi penambahan output dan pendapatan baru pada faktor produksi tersebut akan menambah output nasional sehingga akan terjadi pertumbuhan ekonomi.
Investasi memang tidak bisa dipisahkan dengan pinjaman, dan pinjaman selalu berkaitan dengan bunga, tingkat suku bunga diyakini oleh para ekonom sebagai salah satu determinan investasi. Hal ini menyangkut biaya investasi (cost of investment) yang harus ditanggung oleh investor. Semakin besar biaya investasi maka akan semakin kecil keuntungan yang diperoleh investor, akibatnya semakin rendah minat berinvestasi. Hal ini dibuktikan dengan melambungnya tingkat suku bunga pada masa krisis yang menyebabkan menurunnya investasi domestic.

Dalam memeperhitungkan nilai keuntungan disamping mempertimbangkan tingkat suku bunga investor juga harus mempertimbangkan seberapa besar permintaan terhadap barang dan jasa yang akan dihasilkan dalam investasinya. Secara teoritis, besar 
kecilnya permintaan terhadap barang dan jasa sangat bergantung pada kuat lemahnya daya beli masyarakat, yang dicerminkan oleh besar kecilnya pendapatan riil. Dengan demikian pendapatan riil juga memiliki peran sebagai determinasi dalam investasi. Dalam perekonomian pendapatan ini biasa dilihat dari Produk Domestik Bruto (PDB).

Model dinamis (Dynamic Model) merupakan salah satu alat analisis yang dapat digunakan untuk mengevaluasi dampak jangka pendek dan jangka panjang dari suatu kebijakan. Dalam pengeluaran investasi, perubahan baik itu kebijakan pemerintah mengenai kegiatan investasi saat ini baru sering terlihat beberapa bulan bahkan beberapa tahun kemudian, hal ini disebabkan oleh dua faktor utama. Pertama, investor tidak bisa langsung mengantisipasi kebijakan tersebut, karena aktivitas investasi mempunya tenggang waktu (lag time) mulai dari pengambilan keputusan berinvestasi sampai realisasi investasi. Kedua, kebijaksanaan tersebut sering mempunya pengaruh yang lambat terhadap perubahan atau perbaikan yang ingin dicapai.

Pengalaman Indonesia selama ini juga menunjukkan betapa pentingnya investasi bagi kelangsungan Pembangunan atau Pertumbuhan ekonomi dalam negeri. Berdasarkan data BPS, sejak awal 2000 ini, PDB Indonesia memang mengalami pertumbuhan positif, setelah dua tahun berturut-turut sebelumnya negatif. Namun laju pertumbuhannya sangat rendah, terutama jika dibandingkan dengan pertumbuhan rata-rata per tahun yang dialami Indonesia pada periode pra krisis. Alasannya sederhana, pergerakan ekonomi nasional sejak akhir 1999 hingga kini lebih didorong oleh pertumbuhan konsumsi bukan oleh pertumbuhan investasi yang signifikan.jika pola pertumbuhan ekonomi terus seperti ini tanpa adanya kontribusi yang berarti dari investasi, dapat dipastikan pertumbuhan tersebut tidak dapat berlanjut terus. (Tambunan, 2000).

Jadi dari uraian di atas, pokok permasalahan yang menjadi pembahasan utama dari tulisan ini adalah iklim investasi yang sangat kompleks, yang implikasinya adalah bahwa kebijakan investasi tidak bisa berdiri sendiri. Dalam kata lain, bagaimanapun bagusnya suatu kebijakan investasi, efektivitas dari kebijakan tersebut akan tergantung pada banyak faktor lain di luar wilayah kebijakan investasi, karena faktor-faktor tersebut sangat mempengaruhi keputusan seseorang untuk melakukan investasi selain itu juga realisasi dari suatu kegiatan investasi memerlukan waktu yang tidak singkat dan bersifat dinamis. Dengan Penggunaan model dinamis dapat mengestimasi hubungan faktor pendapatan nasional, tingkat suku bunga serta investasi PMDN periode sebelumnya terhadap permintaan investasi.

Dengan mengacu pada fenomena investasi yang begitu besar pengaruhnya terhadap stabilitas perekonomian di Indonesia. Maka tulisan ini lebih terfokus untuk melihat apakah pendapatan nasional, tingkat suku bunga kredit investasi dan investasi dalam negeri (PMDN) periode sebelumnya mempengaruhi investasi dalam negeri (PMDN) serta variabel mana yang mempengaruhi dominan terhadap investasi dalam negeri (PMDN).

\section{METODE PENELITIAN}

Untuk menengetahui konsep atas variabel yang akan diteliti, maka diketahui masing-masing variabel yaitu sebagai berikut: Variabel Dependent yaitu Investasi. Nilai investasi yang 
digunakan dalam penelitian ini adalah nilai investasi dalam negeri yang telah disetujui oleh pemerintah Indonesia yang dipublikasikan oleh Badan Koordinator Penanaman Modal (BKPM) periode tahun 2004-2007.

Variabel Independent yaitu Pendapatan nasional, tingkat suku bunga, investasi dalam negeri tahun sebelumnya. Pendapatan Nasional $\left(\mathrm{X}_{1}\right)$, diartikan sebagai jumlah seluruh nilai hasil produksi barang-barang dan jasajasa yang dihasulkan oleh penduduk suatu Negara dalam periode tertentu (satu tahun). Data pendapatan nasional yang dipakai adalah PDB dari tahun 2004-2007 Atas Dasar Harga Konstan 2000.

Tingkat suku bunga kredit $\left(\mathrm{X}_{2}\right)$ yang digunakan adalah tingkat suku bunga kredit investasi dari tyang berlaku pada bank-bank umum di Indonesia tahun 2004-2007.

Investasi dalam negeri (PMDN) periode sebelumnya merupakan syarat utama dalam perhitungan model PAM. Dalam hal ini investasi PMDN sebelumnya adalah jumlah investasi PMDN pada periode sebelumnya dimana data ini diperoleh dari Statistik Ekonomi dan Keuangan Indonesia.

Untuk mengetahui pengaruh variabel-variabel tersebut terhadap investasi PMDN metode regresi berganda. Dalam penelitian model awal yang digunakan dalam penelitian ini adalah sebagai berikut:

It* $=\alpha_{0}+\alpha_{1} Y_{t}+\alpha_{2} r_{t}+e_{t}$

Dimana: It ${ }^{*}=$ Investasi dalam negeri (PMDN) jangka panjang; Yt = Pendapatan Nasional; $r_{t}=$ Tingkat Suku Bunga; $\quad \alpha_{0}, \quad \alpha_{1}, \alpha_{2}, \alpha_{3}=$ Koefisien Regresi; $\mathrm{e}_{\mathrm{t}}=$ Error term

Dikarenakan nilai dari investasi PMDN optimal It* tidak didapat datanya di lapangan maka dideteksi melalui penyesuaian atau Partial Adjustment Model (PAM). Jika It* adalah investasi
PMDN optimal pada periode $\mathrm{t}$ dan It adalah nilai actual investasi PMDN maka model penyesuaian atau PAM dapat dijelaskan sebagai berikut:

$$
\begin{gathered}
I_{t}-I_{t-1}=\delta\left(I_{t}^{*}-I_{t-1}\right) \\
I_{t}=\delta I_{t}^{*}+I_{t-1}-\delta I_{t-1} \\
I_{\text {䒀 }}=\delta I_{t}^{*}+(1-\delta) I_{t-1}
\end{gathered}
$$

Dimana: It $^{*}=$ Investasi dalam negeri (PMDN) jangka panjang; $\delta=$ Koefisien penyesuaian besarnya $0<\delta<$ 1.

Agar persamaan (1) dapat dicari solusinya maka persamaan (1) disubsitusikan ke dalam persamaan (2) sehingga menghasilkann persamaan sebagai berikut:

$I_{t}=\delta\left(\alpha_{0}+\alpha_{1} Y_{t}+\alpha_{2} r_{t}+e_{t}\right)+(1-$

$\delta) I_{t-1}$

$I_{t}=\delta \alpha_{0}+\delta \alpha_{1} \square_{t}+\alpha_{2} r_{t}+$ $(1-\delta) I_{t-1}+\delta e_{t}$

$I_{t}=\delta \alpha_{0}+\delta \alpha_{1} Y_{t}+\delta \alpha_{2} r_{t}+$ $(1-\delta) I_{t-1}+v_{t}$

Dimana $: v_{t}=\delta e_{t}$

Jika:

$$
\begin{aligned}
& \delta \alpha_{0}=\beta_{0} \\
& \delta \alpha_{1}=\beta_{1} \\
& \delta \alpha_{2}=\beta_{2} \\
& (1-\beta)=\beta_{3} \\
& v_{t}=\mu
\end{aligned}
$$

Maka persamaan (3) menjadi:

$I_{t}=\beta_{0}+\beta_{1} Y_{t}+\beta_{2} r+\beta_{3} I_{t-1}+\mu_{t}$

Dimana: $\mathrm{I}_{\mathrm{t}}=$ Investasi dalam negeri $(\mathrm{PMDN})$ jangka pendek; $\mathrm{Y}_{\mathrm{t}}=$ Pendapatan Nasional; $\mathrm{r}=$ Tingkat Suku Bunga; $\beta_{0}, \beta_{1}, \beta_{2}, \beta_{3}=$ Koefisien Regresi; $\mu \mathrm{t}=$ error term

Sehingga model persamaan jangka pendek menjadi:

$$
L I_{t}=\beta_{0}+\beta_{1} L Y_{t}+\beta_{2} L r_{t}+\beta_{3} L I_{t-1}+\mu_{t}
$$

\section{PEMBAHASAN}

Perekonomian Indonesia sejak tahun 90-an sampai saat ini dibagi menjadi dalam dua periode, yaitu kondisi perekonomian sebelum krisis dan sesudah krisis. Hal ini perlu dipertegas karena untuk memudahkan dalam menganalisis suatu permasalahan khususnya masalah ekonomi. 
Tabel 1. Hasil Uji Akar-Akar Unit (level): variabel Investasi PMDN, Pendapatan Nasional dan Tingkat suku bunga

\begin{tabular}{clccc}
\hline No & Variabel & Nilai DF statistik & $\begin{array}{c}\text { Nilai Kritis Mc } \\
\text { Kinnon }\end{array}$ & Kesimpulan \\
\hline 1 & Investasi PMDN & -7.136103 & -2.9320 & Stasioner \\
2 & Pendapatan Nasional & -5.917067 & -2.9320 & Stasioner \\
3 & Tingkat Suku Bunga & -8.433709 & -2.9320 & Stasioner \\
\hline
\end{tabular}

Tabel 2. Hasil Estimasi Regesi antara Variabel Independent dan Variabel Dependent Investasi PMDN

\begin{tabular}{lcccc}
\hline Variabel Bebas & Koef.Regresi & Simp. Baku & T hitung & Prob \\
\hline Konstanta & -167.0967 & 23.19123 & -7.205168 & 0.0000 \\
$\mathrm{LY}_{\mathrm{t}}$ & 12.41648 & 1.630049 & 7.617241 & 0.0000 \\
$\mathrm{LR}$ & -0.205693 & 0.163385 & -1.258942 & 0.2148 \\
$\mathrm{LI}_{\mathrm{t}-1}$ & 0.515447 & 0.073718 & 6.992158 & 0.0000 \\
\hline $\mathrm{R}^{2}$ & $=0.710696$ & & & \\
$\mathrm{R}=$ Adjust Square & $=0.690512$ & & & \\
$\mathrm{~F}_{\text {hitung }}$ & $=35.21081$ & & & \\
Durbin Wastont Test & $=0.843656$ & &
\end{tabular}

Krisis ekonomi di Indonesia diawali pada pertengahan bulan juli 1997, yang awalnya hanyalah kenaikan nilai dollar terhadap rupiah. Kenaikan ini dipacu oleh para pelaku pasar terutama para spekulan yang membuat nilai rupiah semakin terpuruk. Krisis moneter ini berlangsung cukup lama, yang pada akhirnya menjadi krisis ekonomi yang makin parah dan juga mengakibatkan krisis-krisis di bidang lainnya.

Indonesia bukanlah satu-satunya Negara yang mengalami krisis ekonomi, karena hampir semua Negara di Asia juga mengalami hal yang sama. Yang membedakan dalam krisis antar Negara satu dengan yang lain adalah cara penyelesaiannya.

Korea Selatan adalah salah satu contoh Negara yang berhasil, mengatasi krisis ekonomi, setahun terkena krisis yang hampir membuat bangkrut perekonomian, secara mengejutkan Korea Selatan kemudian bisa membayar kembali dua pertiga dari dana penyelamatan Internasional yang diterimanya. Tidak ada satupun Negara dalam krisis di Asia, bisa melakukan hal ini, selain Korea Selatan.
Sebaliknya Thailand, meskipun tidak sedramatis Korea Selatannjuga membuat kejutan, yakni dengan gagah berani menyatakan "stop" terhadap kucuran dana dari IMF, September tahun 1998 lalu, karena merasa sudah tidak membutuhkannya lagi.

Kondisi ini berbanding terbalik dengan Indonesia, yang bukan saja harus menjadwalkan kembali utang yang sudah waktunya dibayar, akan tetapi Indonesia juga masih mengandalkan utang sebagai sumber pembiayaan dalam pembangunan untuk beberapa tahun mendatang.

Langkah awal dari penelitian ini yaitu pengujian stasioneritas data yang dilakukan terhadap seluruh variabel dalam model penelitian yang dilakukan menggunakan metode Augmented Dickey Fuller Test (ADF-Test), yang perhitungannya menggunakan bantuan Eviews 3.0. Keseluruhan hasil pengujian ADF dapat dilihat di tabel 1.

Hasil pada tabel 1 menunujukkan bahwa semua data sudah berada pada kondisi stasioner. Hal ini terlihat bahwa nilai ADF hit lebih besar dari pada nilai 
kritis Mc Kinnon sehingga pengujian dapat dilanjutkan pada tahap selanjutnya.

Dari hasil pengujian model yang digunakan dalam penelitian ini dapat diketahui bahwa variabel bebas Pendapatan Nasional, tingkat suku bunga kredit investasi, investasi dalam negeri (PMDN) periode sebelumnya berpengaruh terhadap vaiabel terikat investasi dalam negeri (PMDN). Hasil pengujian model regresi dapat ditunjukkan pada tabel 2 .

Berdasarkan tabel 2, hasil analisis regresi dapat ditulis dalam bentuk persamaan regresi sebagai berikut:

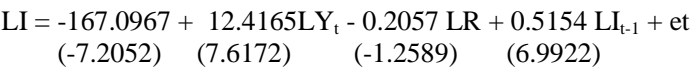

Dimana masing-masing koefisien regresi variabel bebas menunjukkan besarnya perubahan yang akan terjadi pada variabel dependent akibat adanya perubahan sebesar 1 satuan dari masingmasing variabel independent. Masingmasing koefisien tersebut dapat dijelaskan sebagai berikut:

$\beta_{1}=12.41648$; koefisien regresi variabel Pendapatan Nasional sebesar 12.41648, berarti ada pengaruh positif antara PDB terhadap Investasi dalam negeri (PMDN) sebesar 12.41648. Jadi, apabila PDB naik sebesar $1 \%$, maka investasi dalam negeri (PMDN) naik sebesar $12.41648 \%$. Sebaliknya, apabila PDB turun sebesar 1\%, maka investasi dalam negeri (PMDN) akan turun sebesar 12.41648\%. Asumsi, variabel yang lain tetap. Sesuai dengan prinsip akselerasi yang dikemukakan oleh J.M Clark yang menyatakan bahwa tingkat/besarnya investasi secara proporsional bergantung kepada output (PDB), hal ini terjadi karena pengusaha menginnginkan suatu hubungan tertentu dari modal yang diinginkan dengan hasil produksi.

$$
\beta_{2}=-0.205693 ; \text { koefisien regresi }
$$
untuk tingkat suku bunga sebesar -
0.205693. berarti ada hubungan negatif antara tingkat suku bunga terhadap investasi dalam negeri (PMDN) sebesar (0.205693). Jadi, apabila tingkat suku bunga naik sebesar $1 \%$ maka investasi dalam negeri (PMDN) akan turun sebesar 0.205693\%. begitu juga sebaliknya, jika tingkat suku bunga turun $1 \%$ maka investasi dalam negeri PMDN meningkat $0.205693 \%$ dengan asumsi variabel lain konstan.

$$
\beta_{3}=0.515447 \text {, koefisien regresi }
$$

variabel investasi PMDN periode sebelumnya sebesar 0.515447 ; berarti ada pengaruh positif antara investasi dalam negeri (PMDN) periode sebelumnya terhadap investasi dalam negeri (PMDN) sebesar 0.515447. Jadi, apabila investasi dalam negeru (PMDN) periode sebelumnya naik sebesar $1 \%$, maka investasi dalam negeri (PMDN) naik sebesar $0.515447 \%$. Sebaliknya, apabila investasi dalam negeri (PMDN) periode sebelumnya turun sebesar $1 \%$ maka investasi dalam negeri (PMDN) akan turun sebesar $0.515447 \%$. Asumsi, variabel yang lain tetap.

Berdasarkan hasil perhitungan nilai koefisien determinasi $\left(\mathrm{R}^{2}\right)$ melalui analisa regresi ditunjukkan bahwa variabel Pendapatan nasional, tingkat suku bunga, investasi dalam negeri (PMDN) periode sebelumnya mampu menjelaskan $71,07 \%$ variasi besarnya investasi dalam negeri (PMDN). Sedangkan sisanya 28,93\% menunjukkan bahwa variasi besarnya investasi dalam negeri (PMDN) dijelaskan oleh variabel lain yang mempunyai pengaruh namun tidak diamati dalam penelitian ini. Variabel lain yang dimaksud dapat berupa variabel non-ekonomi seperti perubahan dalam bidang sosial politik yang berpengaruh langsung terhadap variabelvaiabel yang mempengaruhi besarnya investasi dalam negeri (PMDN). Oleh karena persentase variasi besarnya 
investasi dalam negeri (PMDN) yang tidak dapat dijelaskan adalah kecil, maka dapat dikatakan bahwa model yang digunakan adalah baik.

Dikarenakan ada kelambanan, hasil dari koefisien jangka pendek untuk Pendapatan Nasional sebesar 12.41648, dan tingkat suku bunga -0.205693 . sedangkan koefisien jangka panjang sebagai berikut:

Untuk variabel PDB $\left(\mathrm{Y}_{\mathrm{t}}\right)$

$\alpha_{1}=\frac{\text { Coeficient }_{t}}{\left(1-L I_{(-1)}\right)}=\frac{12.41648}{(1-0.515447)}=$ 25,6246

Untuk variabel tingkat suku bunga $\left(\mathrm{r}_{\mathrm{t}}\right)$

$\alpha_{2}=\frac{\text { Coeficient }_{t}}{\left(1-L I_{(-1)}\right)}=\frac{-0.205693}{(1-0.515447)}=$ $-0,42450$

Berdasarkan hasil perhitungan koefisien jangka panjang dari PAM di atas, maka dapat dikemukakan bahwa dalam jangka panjang jika Pendapatan Nasional naik sebesar $1 \%$ akan mengakibatkan investasi dalam negeri (PMDN) mengalami kenaikan sebesar 25,6246\%. Begitu pula sebaliknya jika terjadi penurunan Pendapatan Nasional sebesar $1 \%$ akan mengakibatkan investasi dalam negeri (PMDN) mengalami penurunan sebesar $25,6246 \%$. Sedangkan untuk variabel tingkat suku bunga naik sebesar $1 \%$ akan mengakibatkan investasi dalam negeri (PMDN) mengalami penurunan sebesar $0,42450 \%$ begitu pula sebaliknya jika tingkat suku bunga turun sebesar $1 \%$ akan mengakibatkan investasi dalam negeri (PMDN) meningkat sebesar $0,42450 \%$.

Dengan menggunakan test dua arah, tingkat signifikansi sebesar 5\% dan derajat bebas 43 diperoleh t-tabel sebesar 2,021, dapat diketahui bahwa seluruh variabel bebas berpengaruh secara signifikan terhadap varaibel terikat (Investasi).

Dari hasil estimasi regresi diketahui bahwa secara bersama-sama atau serentak berpengaruh secara signifikan terhadap variabel investasi dalam negeri (PMDN). Dari hasil tabel sebelumnya, dapat diketahui nilai Fhitung sebesar 35.21081 sedangkan Ftabel dengan $\alpha=5 \%, \mathrm{df}_{1}=3, \mathrm{df}_{2}=43$ sebesar 2,84. Sehingga F-hitung lebih besar dari F-tabel, karena itu menolak Ho dan menerima Ha. Artinya variabel Pendapatan Nasional, tingkat suku bunga kredit investasi, investasi dalam negeri (PMDN) periode sebelumnya secara bersama-sama atau serentak mempengaruhi variabel terikat investasi dalam negeri (PMDN) secara signifikan dengan tingkat signifikansi sebesar 0,000000 .

Untuk mengetahui variabel yang mempunyai pengaruh paling dominan terhadap besarnya investasi dalam negeri (PMDN) selama periode penelitian tahun 2004 sampai dengan 2007 dapat dilihat nilai probabilitas. Variabel bebas memiliki nilai probabilitas yang terendah menunjukkan bahwa variabel tersebut merupakan variabel yang memiliki pengaruh dominan terhadap variabel terikat.

Berdasarkan hasil perhitungan diperoleh nilai probabilitas untuk variabel Pendapatan nasional, tingkat suku bunga serta investasi dalam negeri (PMDN) periode sebelumnya masingmasing sebesar 0,$0000 ; 0,2148 ; 0,0000$. Dengan membandingkan nilai probabilitas dari masing-masing variabel dapat diambil kesimpulan bahwa variabel yang mempunyai pengaruh paling dominan terhadap besarnya investasi dalam negeri (PMDN) adalah investasi dalam negeri (PMDN) periode sebelumnya serta sesuai dengan model yang digunakan dalam penelitian ini yaitu model penyesuaian parsial (Partial Adjustment Model).

Variabel lain diluar variabel besarnya investasi dalam negeri (PMDN) periode sebelumnya yang memiliki pengaruh dominan terhadap 
besarnya investasi dalam negeri (PMDN) jika dilihat nilai koefisien adalah Pendapatan nasional.

\section{PENUTUP}

Dari analisa data yang telah dilakukan menunjukkan bahwa variabel pendapatan nasional (PDB), tingkat suku bunga kredit investasi dan investasi dalam negeri (PMDN) periode sebelumnya ternyata secara bersamasama atau serentak mempunyai pengaruh yang signifikan terhadap besarnya investasi dalam negeri (PMDN). Hal tersebut dilihat dari $\mathrm{F}$ hitung sebesar 35.21081 lebih besar dari $\mathrm{F}$ tabel yaitu sebesar 2,84.

Oleh karena dalam penelitian ini menggunakan model penyesuaian parsial maka sesuai hasil analisa data diketahui bahwa variabel besarnya investasi dalam negeri (PMDN) periode sebelumnya merupakan variabel yang paling dominan dalam mempengaruhi besarnya investasi dalam negeri (PMDN). Namun di luar variabel investasi dalam negeri (PMDN) periode sebelumnya tersebut bahwa variabel pendapatan nasional (PDB) adalah variabel yan paling dominan pengaruhnya terhadap besarnya investasi dalam negeri (PMDN).

Dari analisis yang telah dilakukan, bahwa pendapatan nasional (PDB) berpengaruh positif terhadap investasi dalam negeri (PMDN), oleh karena itu pemerintah perlu melakukan kebijakan, yaitu bagaimana meningkatkan pendapatan nasional (PDB), diantaranya memperluas lapangan pekerjaan sehingga pendapatan masyarakat meningkat dan berdampak pada pendapatan nasional. Dengan meningkatnya pendapatan nasional secara otomatis investasi dalam negeri (PMDN) akan meningkat.

Tingkat suku bunga yang rendah memang baik dari segi kegiatan investasi, namun dari segi penabung, tingkat bunga yang rendah akan meurunkan minat seseorang untuk menabung dengan pertimbangan tingkat suku bunga yang terlalu rendah. Karena bila tabungan naik, jumlah dana dalam bank sebagai modal investasi juga naik. Untuk menjaga agar investasi terus meningkat, maka tingkat suku bunga juga harus dijaga dalam posisi tertentu, sehingga suatu perusahaan atau seorang pengusaha dapat mengatur keuangan dengan baik.

\section{DAFTAR PUSTAKA}

Bisri, Hasan. 2002. Pengaruh Jumlah Uang Beredar dan Tingkat Suku Bunga terhadap Investasi. Malang: UMM

Dornbusch, Rudiger dkk. 1997. Makroekonomi edisi keempat. Jakarta: Penerbit Erlangga

Gujarati, Damodar N. 2006. Dasardasar ekonometrika, edisi ketiga. Jakarta: Erlangga

Irawan dan M. suparmoko.1992. Ekonomi Pembangunan, edisi ketiga. Yogyakarta: UGM

Kuncoro, Mudrajad. 2007. Metode Kuantitatif Teori dan Aplikasi Untuk Bisnis dan Ekonomi Edisi Ketiga. Yogyakarta: STIM YKPN

Mangkoesoebroto, Guritno. 1992. Teori Ekonomi Makro, edisi kedua. Yoyakarta: STIE YKPN

Mankyu, N.G. 2003. Teori Makroekonomi. Jakarta:Erlangga

Murni, Asfiah. 2006. Ekonomika Makro. Bandung: PT Refika Aditama 
Partadiredja, Ace. 1977. Perhitungan Pendapatan Nasional. Jakarta: PT Pustaka LP3ES Indonesia

Sukirno, Sadono. 1987. Ekonomi Pembangunan. Jakarta: FEUI

Sukirno, Sadono. 2000. Pengantar Teori Makro. Jakarta: PT Raja Grafindo Persada

Sunariyah. 2006. Pengantar

Pengetahuan Pasar Modal, Edisi

Kelima. Yogyakarta: UPP

STIM YKPN

Thomas, Leighton. R. 1983.

Introductory Econometrics:

Theory and Applications.

London:Longman

Tim Dosen. 2005. Bahasa Indonesia untuk Karangan Ilmiah Makalah

- Skripsi - Tesis - Disertasi. Malang: UMM Press

Waluyo, Eko Dwi. 2006. Teori Ekonomi Makro. Malang: UMM Press

Widarjono, Agus. 2005. Teori dan Aplikasi untuk Ekonomi dan Bisnis. Jogjakarta:Ekonisia FE UII

www.jawapos.com diakses tanggal 1 Februari 2010

www.bkpm.go.id diakses tanggal 1 Februari 2010 